\title{
Conundrums on the Construction of Instructional Materials in Social Studies
}

\author{
Willan Keith A. Badidles, $\mathrm{LPT}^{a}$, Elizabeth M. Quimbo, $\mathrm{PhD}^{b}$ \\ ${ }^{a}$ williamk.badidles@lnu.edu.ph \\ ${ }^{a}$ Leyte Normal University, P. Paterno Street, Tacloban City 6500, Philippines \\ ${ }^{b}$ Leyte Normal University, P. Paterno Street, Tacloban City 6500, Philippines
}

\begin{abstract}
The K to 12, a reform in Philippines' educational system was signed into law back in 2013. In the Philippine context there is lack of appropriate instructional materials aligned with the $\mathrm{K}$ to 12 curriculum standards. Without the appropriate tools aligned with Edgar Dale's Cone of Experience and Jerome Bruner's Constructivism, teaching-learning process will not be efficient and effective. Thus, it is important to address this concern. This research used qualitative descriptive single-case study which aims to identify problems encountered by the Grade VIII Social Studies classes with regards to the use instructional materials through purposive sampling. The data gathered in the intensive interview was analyzed through thematic process. In the absence of teaching tools, this study could provide suitable instructional materials that could fill-up the gap on the availability of appropriate instructional materials.
\end{abstract}

Published by IJRP.ORG. Selection and/or peer-review under responsibility of International Journal of Research Publications (IJRP.ORG)

Keywords: Instructional Materials, K to 12 Curriculum standards, Descriptive single-case study, Thematic process.

\section{Introduction}

The Department of Education through DepEd Order 021 s., 2019, defined learning resources as teaching and learning materials. These are used to improve learners' knowledge abilities and skills. Instructional materials are imperative in the teaching and learning process. It supports students' higher retention or grasp on different subject areas. According to Nwike \& Catherine (2013) said that there is a positive impact of instructional materials on students' cognitive achievement. Also, they found out learners who were taught with the use of instructional materials performed better than those who had none. Thus, it is important that school administrators should provide various trainings and seminars to teachers in the production and usage of teaching and learning materials. With this, teachers will develop professional growth not only in instructional materials construction but also in terms of teaching strategies (Brucal et al., 2018). Truly, the use and construction of developmentally appropriate materials is essential for the benefit of the learners.

\section{Review of Related Literature}

\subsection{The Curriculum}

There are outcomes required by the 21 st century education system. This change in direction for learning outcomes affects teaching methods (Greeno, Collins, \& Resnick, 1996; Sung, Chang, Chang, \& Yu, 
2010; Hack \& Kendall, 2005; Sharma, 2000; Sung et al., 2010 cited by Nalbantoglu, 2017). Social Studies in the Philippine curriculum aims to create learners with a definite identity and role as Filipino participating in the life of society, nation and world. To achieve these objectives, the curriculum puts emphasis on the interconnected abilities in the Social Studies: (i) investigation; (ii) evaluation and interpretation of information; (iii) research; (iv) communication, specifically in writing essays; and (v) implementing ethnical rules (Official Gazette of the Republic of the Philippines, n.d.,2013).

\subsection{Construction and Use of Instructional Materials}

There are various variables to consider in order to deliver knowledge for students' optimal development. Instructional materials are used by teachers to support learning process which can be obtained from varied sources and arranged systematically (Jannah et al., 2017). The use of Multiple instructional media allows students to use higher metacognitive skills (Thomas, 2018). This cannot take place without the availability of instructional materials and physical facilities (Afework and Asfaw, 2014 cited by Sephania, at al., 2017). Instructional Materials have large effects on student learning but few researches exist on the effectiveness of instructional materials (Chingos and Whitehurst, 2012). Thus, it is very significant to conduct research on the usage of instructional materials. Shortage of instructional materials and teachers who are not adequately using them result to students losing interest in the subject area (Aina, 2013).

Rivera \& Sanchez (2020) said that contextualized instructional materials are efficient in achieving maximum learning potential of learners' in their academic performance. The Department of Education through its incentive program on the production of instructional resources, encourages teachers and administrators in both division and regional levels to produce quality and contextualized teaching and learning materials. It follows certain steps in developing resources, to wit: (1) Inventory, assessment and evaluation; (2) Development and contextualization materials; (3) Pilot testing, review and approval; (4) Publication and Distribution; and (5) Monitoring and reporting (DepEd Order 021 s., 2019). However, teachers need trainings on how to produce and use instructional materials. (Piskurich, 2015).

The primary purpose of teaching and learning process is to bring a significant change in positive behavior through active participation and critical thinking of the learners (Afework and Asfaw, 2014 cited by Sephania et al., 2017). Learners strive to understand their everyday experiences. They relate their social and artificially constructed environment with their natural environment in learning (Zemelman et al., 1998 as cited by Diffily, 2002). It is necessary then to produce instructional materials that contextualizes learning. According to Herbart (1901), students' prior knowledge should be considered in making an instructional model. This should relate to the subject of interest to understand the new concept (Bybee et al., 2006) Experts agree that teaching and learning are more powerful when they are meaningful, integrative, challenging and active (Diffily, 2002).

\subsection{Use of Instructional Materials in Teaching Social Studies}

The current Social Studies learning tends to be "cursory coverage of a lockstep curriculum, memorization of isolated facts and narrowing social studies activity to include only textbook reading and test taking" (Zemelman, et al. 1998 as cited by Diffily, 2002) Schoolwork, not only in Social Studies but across the curriculum, requires deepening of conceptual learning. Students experiencing higher levels of authentic instruction and assessment achieve more than students who do not (Carmichael et al., 2015). 
The Multicomponent Social Studies instruction like structured pairing, strategic use of video to build concepts and promote discussion, and use of graphic organizers gave significant difference to students' curriculum-based vocabulary and comprehension (Martinez et al., 2009).

\section{The Research Problem}

The research uses a descriptive single-case study which (Baxter and Jack, 2008). The researcher would like to answer the question, "What are the issues and concerns with regard to instructional materials production and utilization in the discipline of Grade 8 Social Studies in the current K to 12 Enhanced Basic Education Program?

It is imperative that the development and utilization of instructional materials should be aligned with the conceptual framework of the curriculum. It should respond to the goals of Social Studies education which aims to create learners with a definite identity and role as a citizen participating in the life of society, nation and world.

\section{Theoretical Framework}

Adhering to Jerome Bruner's Constructivist theory, learning is an active process to which learners construct new ideas or concepts based on their extant and previous knowledge (Bruner, 1985). This lead to the proposal of three modes of representation: Enactive representation (action-based), Iconic representation (image-based), Symbolic representation (language-based) (Bruner, 1966) Based on Jerome Bruner's Theory of Development, eight grade students are already in the symbolic representation level but the prior stages should still be considered in developing and utilizing appropriate instructional materials. It could still be an advantage to learning or disadvantage depending on the teacher's way of implementing the curriculum.

Dale integrated Bruner's (1966) three modes of learning into the Cone of Experience by categorizing learning experiences into three modes (Lee and Reeves, 2007). Concept development of learners can be represented by a cone of progression starting from concrete to abstract (Dale, 1946). Teachers then, should attain balance, concrete and abstract, in facilitating effective and meaningful learning. The use of variety of materials and medium is needed in order to maximize the learning experience. Appropriate instructional materials aid to develop higher order thinking skills.

\section{Methodology}

The study used the case study methodology by Yin (1994). There are four stages of the methodology that includes designing the case study protocol which is done in the first phase of the study, conducting the actual case study, analyzing the case study evidence and developing conclusions, recommendations and implications based on the evidences gathered. 


\subsection{Research Design}

This research is a qualitative descriptive single-case study by Yin (2003). The researchers would like to describe the experiences of the teachers and their involvement in developing and utilizing instructional materials in the processes of teaching and learning. This would help in assess the $\mathrm{K}$ to 12 program and develop interventions (Baxter and Jack, 2008; Yin, 2011; Yin, 2017).

\subsection{Data Collection}

The researchers went to a secondary school that was recommended by the Department of Education Schools Division of Tacloban City. It was a pre-identified low performing school. The participants, eighth grade teachers, were identified through purposive sampling used by Fraenkel, Wallen, \& Hyun (1993) Using the semi-structured interview following Drever, (1995) Approved by the interviewees, the researchers used a recorder.

\subsection{Data Analysis}

The participants' responses were coded and analyzed through thematic analysis by Braun and Clarke (2006). The thematic analysis takes in cutting across data and searching for patterns and themes (Boyatzis, 1998; Braun and Clarke, 2006; Vaismoradi, Turunen, and Bondas, 2013). Thematic analysis is performed through the process of coding in six phases- (1) familiarization with data, (2) generating initial codes, (3) searching for themes among codes, (4) reviewing themes, (5) defining and naming themes, and (6) producing the final report- to create established, meaningful patterns (Braun and Clarke, 2006). In analyzing qualitative data, thematic analysis offers an accessible and theoretically flexible approach (Boyatzis, 1998, Braun \& Clarke, 2006).

\subsection{Ethical Considerations}

For confidentiality, the researchers did not divulge the name of the teachers and the school. Approval of the Department of Education, Division of Tacloban City was sought before conducting the research. The principal and the teachers were informed before the actual research visit.

\subsection{Triangulation}

To establish the validity of the study, the researchers conducted field observation with regard to the classrooms and actual instructional materials used. Documentation was done and the researchers also had short interview with some of the students.

\subsection{Reflexivity}

The researchers are instructors in a university. Thus, they are aware of the common struggles teachers encounter in day-to-day bases. Furthermore, two of the researchers are Social Science teachers and one is an IT teacher. The researchers did their best to follow the systematic process in conducting, collecting, and analyzing the data to avoid biases. 


\section{Results and Discussion}

In the ever-changing glass ceiling of economic and social marginalization, educators must use multiple media to accommodate the various learning styles we encounter in our classrooms (Thomas, 2018). Use of appropriate instructional material is not manifested. Shortage of Instructional Materials and teachers who are not adequately using them results to students losing interest in the subject area Aina, (2013).

"The use of Technology could motivate students especially in a Social Studies class... I had trainings on how to use ICT tools...? But there is very limited ICT equipment in school." (P1;L243-246; P6)

\subsection{Theme I. Scarcity of Materials}

In the development of instructional materials, resources such as audio-visual materials (laptops, LCD projectors, computers and Television) and print-text based materials (text books activity sheets) are limited. The teacher uses her personal laptop in developing assessment tools, Visual materials and text materials. The school has only three printers for fifty-seven teachers placed at the principal's office, that is, one printer per nineteen teachers. Two projectors are in count but the teacher never access teaching because only the person in-charge uses the said projectors. A TV is available but it can't be transported from one class to another. The Textbooks are available but can't be brought home.

“...we have two LCD projectors in school but we don't have access to these... we can't reserve nor schedule our use of the projector" (P1; L41-43, L45-46; P1\&2)

"We have one 42 inch TV which was donated by the city government... quite bigger than the one destroyed by typhoon Yolanda. In my one class... I connect my laptop to the TV" (P1; L41-45; P2)

“...we only have 80 books... we don't allow students to bring books at home. Instead, we ask them to jot down notes while in school. (P1;L7071, L74-75; P2)

“...there is 3:1 student and book ratio. ”(P1; L82-83; P2)

"I have shown video clippings to my students... but a single laptop can't accommodate all 50 students.” (P1; L221-223; P5)

\subsection{Theme 2. Difficulty of Production}

There was a limited number of equipment that could aid the teacher in producing instructional materials. Only three printers were shared by 70 faculty members. No photocopy machine was available to support the fast production of printed materials. The teacher spent personal money to produce learning materials for the VIII grade classes. Difficulty in producing quality material was experienced due to the lack of resources.

\footnotetext{
“...using my personal money, I usually print learning materials ... some
} 
came from the soft copy that were given to us. I use the printed materials conducting group activities" (P1; L85-87; P2)

"I re-encode notes for my students... but sometimes, on a PDF document... since I can't copy it. I just Screenshot and paste it on a Word document" (P1; L262-264; P6)

"we only have three printers in school situated at the office of our principal... hmmm... that is never enough for 70 teachers... we also don't have photocopy machine" (P1; L348-350; P8)

"Sometimes, I visualize my students having their own 1:1 ratio of books

exploring by themselves. It hurts!” (P1; 241-242; P6)

\subsection{Theme 3. Utilization of Materials}

The teacher was not able to maximize the utilization of the extant instructional materials like books and module due to its erroneous content and substandard materials. Chalkboards were dilapidated. There was an observable shortage of Information Communication Technology tools such as Speakers/radios, Networked computers, Television and internet.

"Aside from typographic errors, I was also able identify errors on the content in the books the we are using... some were already long existing errors" (P1; L82-83; P2)

"In a class... out of fifty students there is usually two or three who has laptop. I ask them to bring it in school. So we could make use of it." (P1; L221-230, page 5)

"Without an aid, it takes me time to make my students fully understand my topic. So, I did "chalk and talk" to swift the discussion but still, we have dilapidated chalkboards." (P1; L271-273; P6)

"We have few numbers of computer but due to lack of classrooms, it was just put aside. I don't even know if those are still working. (P1; L245246;P6)

\section{Summary}

It is very apparent that Scarcity of Materials, Difficulty of Production and Utilization of Materials greatly affect the development and use of instructional materials. There should be availability of audio-visual materials and print-text based materials which has ratio equal between the teachers and students. It is important to take note that without such materials learning experiences will be restricted. In another point, it is a problem to develop instructional materials with scarce number of equipment that could aid the teacher in the production. Also, teachers cannot maximize the utilization of the extant instructional materials due to its erroneous content and substandard materials used. Teachers give extra time correcting the current materials given to them. 


\section{Conclusion}

Studies prove that learning materials motivate students to learn more. Thus, there is a need of ICT tools integration in the didactics and activities in teaching $21^{\text {st }}$ century learners. However, the unavailability of resources for production hinder the development of instructional materials. With this, teachers resort in using traditional instructional materials. Teachers utilized alternative instructional materials such as photocopied texts and modules taken from the internet sources. This resulted to additional financial burden to teachers. In this case, production and utilization of learning materials became a burden. Furthermore, teachers who lack trainings and seminars in production of instructional materials have less know-how in creating an alternative teaching and learning materials. They then relied on books which are very limited in number and has content errors.

\section{Recommendation}

School administrators together with the Department of Education should initiate the construction and use of varied instructional materials that are aligned with the conceptual framework of the curriculum. Also, teachers should be trained to produce alternative learning material in the absence of books and ICT tools.

\section{References}

Aina, K. J. (2013). Instructional materials and improvisation in physics class: Implications for teaching and learning. Computer, 2(20), 8.

Baxter, P., \& Jack, S. (2008). Qualitative case study methodology: Study design and implementation for novice researchers. The qualitative report, 13(4), 544-559.

Boyatzis, R. E. (1998). Transforming qualitative information: Thematic analysis and code development. sage.

Brucal, J. W., Quilaton, A.K., Tampucao, J and Mandigma, E. C., Jr. (2018). Instructional Materials in Teaching Literature in the Unified Schools of the Archdiocese of Lipa. International Journal of Recent Innovations in Academic Research, 2(6), 8-14.

Bruner, J. S. (1961). The act of discovery. Harvard educational review.

Bruner, J. S. (1966). Toward a theory of instruction (Vol. 59). Harvard University Press.

Bruner, J. (1985). Models of the learner. Educational researcher, 14(6), 5-8.

Braun, V., \& Clarke, V. (2006). Using thematic analysis in psychology. Qualitative research in psychology, 3(2), 77-101.

Bybee, R. W., Taylor, J. A., Gardner, A., Van Scotter, P., Powell, J. C., Westbrook, A., \& Landes, N. (2006). The BSCS 5E instructional model: Origins and effectiveness. Colorado Springs, Co: BSCS, 5, 88-98.

Carmichael, D. L., Newmann, F. M., \& King, M. B. (2015). Authentic intellectual work: Common standards for teaching social studies. In Social Studies Today (pp. 63-74). Routledge.

Chingos, M. M., \& Whitehurst, G. J. (2012). Choosing Blindly: Instructional Materials, Teacher Effectiveness, and the Common Core. Brookings Institution. 
Dale, E. (1969). Audiovisual methods in teaching.।

DepEd Order 021 s., 2019. Policy and Guidelines on the K to 12 Basic Education Program. Retrieved from: https://www.deped.gov.ph/wp-content/uploads/2017/04/DM_s2017_082.pdf

Drever, E. (1995). Using Semi-Structured Interviews in Small-Scale Research. A Teacher's Guide.

Diffily, D. (2002). Project-based learning: meeting social studies standards and the needs of gifted learners. Gifted child today, 25(3), 40-59.

Jannah, L., Suharno, S., \& Triyanto, T. (2017). The Needs for Multicultural Knowledge in Instructional Material on Theme 7" Beautiful Diversity in My Country" Grade 4th Elementary School. Journal of Education and Learning, 11(3), 307-311.

Lee, S. J., \& Reeves, T. C. (2007). Edgar Dale: A significant contributor to the field of educational technology. Educational Technology, 47(6), 56. Piskurich, G. M. (2015). Rapid instructional design: Learning ID fast and right. John Wiley \& Sons.

Molenda, M. (2003). Cone of experience. Educational technology: An encyclopedia.

Nalbantoglu Yilmaz, F. (2017). Reliability of Scores Obtained from Self-, Peer-, and Teacher-Assessments on Teaching Materials Prepared by Teacher Candidates. Educational Sciences: Theory and Practice, 17(2), 395-409.

Nwike, M. C., \& Catherine, O. (2013). Effects of use of instructional materials on students cognitive achievement in agricultural science. Journal of Educational and Social Research, 3(5), 103.

Official Gazette of the Republic of the Philippines (n.d.). (2013). The K to 12 basic education program.

Rivera, G. M., \& Sanchez, J. M. P. (2020). Use of Contextualized Instructional Materials: The Case of Teaching Gas Laws in a Public Uptown High School. Orbital: The Electronic Journal of Chemistry, 12(4), 276-281.

Sephania, N., Too, J. K., \& Kipng'etich, K. J. (2017). Perception of teachers on availability of instructional materials and physical facilities in secondary schools of Arusha District, Tanzania.

Thomas, K. S. (2018). Using Multiple Instructional Mediums to Foster Critical Literacy Skills with the Adult Linguistic Diverse Learner. Social Science and Humanities Journal, 322-334.

Vaughn, S., Martinez, L. R., Linan-Thompson, S., Reutebuch, C. K., Carlson, C. D., \& Francis, D. J. (2009). Enhancing social studies vocabulary and comprehension for seventh-grade English language learners: Findings from two experimental studies. Journal of Research on Educational Effectiveness, 2(4), 297-324.

Vaismoradi, M., Turunen, H., \& Bondas, T. (2013). Content analysis and thematic analysis: Implications for conducting a qualitative descriptive study. Nursing \& health sciences, 15(3), 398-405.

Yin, R. K. (1994). Case study research: Design and Methods, Applied social research methods series,

5. Biography, Sage Publications, London. 
Yin, R. K. (2011). Applications of case study research. Sage.

Yin, R. K. (2017). Case study research and applications: Design and methods. Sage publications. 